\title{
TWO NEW SPECIES AND A NEW COMBINATION IN
} ECHINOCHLOA

P.W. Michael. AND Joyce W. Vickery (Received February 1974)

\section{ABSTRACT}

Michael, P.W. (Department of Agronomy and Horticultural Science, University of Sydney, New South Wales, Australia) and Joyce W. Vickery (National Herbarium of New South Wales, Royal Botanic Gardens, Sydney, New South Wales, Australia) 1975. Two New Species and a new Combination in Echinochloa. Telopea 1 (1): 44-48. Echinochloa telmatophila Michael et Vickery and $E$. intundata Michael et Vickery are described and the combination E. lacunaria (F. Muell.) Michael et Vickery is effected.

The writers have been engaged for some time in a taxonomic study of the species of Echinochloa occurring at present in Australia and New Guinea. The following new combination and descriptions of two new species provided now as names for these taxa are required for use in a treatment of the genus for the Flora of New South Wales.

Echinochloa lacunaria ( $F$. Muell.) Michael et Vickery, comb. nov. (1855).

Basionym: Panicum lacunarium F. Muell. in Trans, \& Proc. Victorian Inst. 1854/5: 47

SYNONYMS: Panicum crus-galli var. lacunarium (F. Muell.) F. Muell., Fragm. 8: 198 (1874). Echinochloa cris-galli var. lacumaria (F. Muell.) Hughes in Kew Bull. 1923: 320 (1923).

Echinochloa telmatophila Michael et Vickery, sp. nov.

Gramen annuum saepe robustum erectum vel erecte expansum aliquando ad nodos inferiores radicatum. Culmi usque ad $180 \mathrm{~cm}$ alti, deorsum saepe usque ad $1 \mathrm{~cm}$ diametro, sursum graciliores, 5-6 nodi, teretes vel sursum compressi glabri laeves nitentes leviter striati, saepe aliquanto latere uno canaliculati, simplices vel nodis inferioribus mediisque ramosi. Vaginae plerumque glabrae vel rarissime pilis sparsis longiusculis mollis basi tubercularis, saepe quam internodos longiores, striatae plus minusve compressae et sursum carinatae. Ligula glabra vel minutissime pubescens. Laminae planae lineares usque ad 35 $\mathrm{cm}$ longae et $18 \mathrm{~mm}$ latae, basi breviuscule augustatae, apices acuminatos versus attenuatae, glabrae vel aliquando basin versus ad margines pilis paucis basi tubercularibus, plerumque scabrae vel paginis inferioribus sublaevibus, nervis mediis manifestis canescentibus et circa 5 nervis primariis utrimque instructis, marginibus manifeste vel anguste incrassatis saepe canescentibus scabris. Panicula plerumque purpurascens vel primum virescens, plerumque ampla densaque 20-35 $\mathrm{cm}$ longa erecta vel paullo nutans, linearis vel lanceolata vel elliptica, ramis plerumque numerosis appressis vel erecte expansis, axe primario angulari angulis scabrissimis, nodis setis numerosis instructis; rami distantes vel approximati 1 vel pluri-nati $2-10 \mathrm{~cm}$ longi simplices vel ramulis secondariis brevissimis, spiculis plerumque longe aristatis plerumque densiuscule vestitis, rhachide angularetriquetra scabrissima plerumque setis numerosis instructa. Spiculae plerumque appressae plus minusve densae 2 - vel 3-natae angustiuscule ellipticae, in bases brevissimas constrictas gradatim angustatae, 3-4.2 mm longae, glumis et lemmate inferiore membranaceo-herbaceis. Gluma inferior basem amplectans, basin versus 
gradatim angustata non vel vix inflata, acuta vel longe acuminata, longitudine $\frac{1}{3}-\frac{1}{2}$ eae spiculae, 3-5-nervata scabro-pubescens. Gluma superior spiculam aequilonga, in dorso convexa acuminata, cuspidata vel aristata arista scabra usque ad $7 \mathrm{~mm}$ longa, 5-nervata nervis praesertim lateralibus spinulosa, inter nervos scabro-pubescens. Flosculus inferior neuter: Lemma glumam superiorem simulans sed ad dorsum planum, 7-nervatum, nervis omnibus lateralibus spinulosum inter nervos scabro-pubescens, ad nervum medium plus minusve sine spinulis, $0.5-1 \mathrm{~mm}$ longis erecto-expansis, longe aristatum arista plerumque purpurascente $1-4 \mathrm{~cm}$ longa; palea anguste oblonga vel lanceolato-oblonga apicem versus angustata hyalina, lemma saepe aequans. Flosculus superior hermaphroditus angustiuscule ellipticus planoconyexus $3-4.1 \mathrm{~mm}$ longus $1.25-1.5 \mathrm{~mm}$ latus laevis et nitens: Lemma breve vel longiuscule cuspidatum dorso convexum tenuiter crustaceum obscure 5-nervatum, dorso anguste sed obtuse e cuspide scabro demarcata et junctura aliquando minute pubescens; palea lemma in textura simulans et subaequans sed ad dorsum plana, marginibus tenuioribus granum amplectentibus basi paullo latioribus. Antherae (0.6-) $0.8-1.3(-1.5) \mathrm{mm}$ longae. Caryopsis $1.8-2.3 \mathrm{~mm}$ longa, $1.2-1.35 \mathrm{~mm}$ lata, oblonga pallida, embryone longitudine circa $\frac{3}{4}$ caryopsidis partes aequanti.

Holotype: New South Wales: Central Coast: Lane Cove National Park, M. Gray 5201, 3.iii. 1962 (CANB 120623, 120625).

Erect or erectly spreading, often robust annual up to $180 \mathrm{~cm}$ high, sometimes rooting at the lower nodes. Culms often stout and up to almost $1 \mathrm{~cm}$ in diameter towards the base, more slender upwards, 5- to 6-noded, terete or somewhat compressed upwards, glabrous, smooth, shining, lightly striate, often somewhat grooved on one side, often more or less concealed by the sheaths, simple or branching from the lower and middle nodes. Nodes glabrous. Sheaths usually glabrous, or the lower very rarely sparsely furnished with rather long, soft, tubercle-based hairs, often longer than the internodes, somewhat compressed and keeled upwards. Ligule absent, the ligular area glabrous or minutely pubescent, the collar sometimes minutely pubescent. Blades flat, linear, up to $35 \mathrm{~cm}$ long and $18 \mathrm{~mm}$ wide, rather shortly narrowing into the sheath at the base, attenuate towards the acuminate apex, glabrous except sometimes with a few tubercle-based hairs on the margins near the base, usually scabrous on the upper or both surfaces or the lower surface subsmooth, the manifest midrib whitish with about 5 primary nerves on each side of it, the margins distinctly or narrowly thickened and often whitish, scabrous. Panicle purplish or greenish, usually large and dense, $20-35 \mathrm{~cm}$ long, erect or slightly nodding, linear to lanceolate or elliptical in outline, with usually numerous, appressed to erectly spreading branches; main axis angular, very scabrous on the angles and on the nerves between them, with numerous setae at the nodes; branches distant or approximate, 1- to several-nate, 2-10 cm long, simple or with very short secondary branches, usually rather densely clothed with generally long-awned spikelets, the rhachis angular-triquetrous, very scabrous, usually with rather numerous branch setae. Spikelets usually appressed, more or less closely arranged, 2- to 3-nate, rather narrowly elliptical in outline and usually narrowing evenly towards the very short constricted base, 3-4.2 $\mathrm{mm}$ long, the glumes and lower lemma membranous-herbaceous. Lower glume embracing the base of the spikelet, narrowing evenly towards the very short constricted base, not or scarcely inflated, acute to long-acuminate, one-third to more than one-half the length of the spikelet, 3- to 5-nerved, scabrouspubescent. Upper glume as long as the spikelet and similar in outline, convex on the back, acuminate, cuspidate or awned with the scabrous awn up to $7 \mathrm{~mm}$ long, 5-nerved, spinulose on the nerves especially the lateral nerves and scabrouspubescent between the nerves. Lower floret neuter: Lemma similar to the upper glume but flat on the back, 7-nerved, spinulose on all the lateral nerves and scabrous-pubescent between them, the spinules more or less wanting on the 
median nerve and the back therefore more or less smooth, the spinules $0.5-1$ $\mathrm{mm}$ long, erectly spreading, the lemma almost always long-awned with the awns often purplish and 1-4 cm long; palea narrowly oblong to lanceolate-oblong, narrowing towards the apex, hyaline, often nearly as long as the lemma. Upper floret rather narrowly elliptical, planoconvex, 3-4.1 $\mathrm{mm}$ long, $1.25-1.5 \mathrm{~mm}$ wide, smooth, shining, pale yellowish-grey at maturity: Lemma short- to rather long-cuspidate, convex on the back, thinly crustaceous, obscurely 5-nerved, the smooth back narrowly but obtusely defined from the scabrous cusp and the junction sometimes marked by a line of minute pubescence; palea similar to the lemma in texture and almost as long but flat on the back, the thinner margins embracing the grain. Anthers (0.6-) $0.8-1.3$ (-1.5) $\mathrm{mm}$ long. Grain 1.8-2.3 $\mathrm{mm}$ long, $1.2-1.35 \mathrm{~mm}$ wide, oblong, pale creamy-yellowish to pale brownish, the embryo about three-quarters as long and oblong.

Distribution: In mud at the margins of streams and ponds in coastal districts from Bulli (Central Coast), New South Wales, northwards to the Burnett and Wide Bay districts in Queensland, and occasional near Perth in Western Australia.

Derivation of telmatophila: Greek telma, telmatos=pool or mud; phileo=I love.

\section{Echimochloa inundata Michael et Vickery, sp. nov.}

Gramen annuum viride vel pallido-viride erectum vel basin versus aliquanto geniculatum. Culmi usque ad $120 \mathrm{~cm}$ altum, deorsum usque ad $8 \mathrm{~mm}$ in diametro, sursum graciliores laeves, circa 5-nodi, teretes vel aliquanto naturaliter compressi sed pressione facile complanati, simplices vel sparse ramosi. Vaginae internodia aequantes vel superantes, superiores culmos arcte amplectentes vel aliquanto inflatae (inferiores tandem laxae), primum firme herbaceae tandem aliquanto tenues chartaceaeque, laeves et striatae. Ligula glabra. Laminae lineares planae in apices acutos vel acuminatos angustatae, basin versus leniter rotundatae, usque ad $30 \mathrm{~cm}$ longae et $12 \mathrm{~mm}$ latae, nervis mediis canescentibus nervis primariis tenuibus 5-6 utrimque instructis, marginibus anguste canesco-incrassatis scabrisque, alias laeves vel basin versus interdum pilis paucis longis basi tubercularibus. Panicula tandem exserta, 7-20 cm longa vix 3-4 cm lata, paullo nutans, angusta, sublinearis, racemis brevibus erectis vel anguste patentibus, axe primario paullo flexuoso scabrido triquetro angulis scabris, ad nodos setis basi tubercularibus paucis et inter nodos setis paucis vel nullis instructo, racemos numerosos distantes internodos aequantes vel superantes 1-natos vel 2-3-natos et subverticillatos basin versus sparse ramosos ramulis brevibus appressis gerenti; racemi inferiores $2-7 \mathrm{~cm}$ longi, superiores gradatim breviores spiculis modice densis vel paullo laxis instructi, rhachide triquetra scabrida ad angulos scabra setis nullis vel paucis. Spiculae binatae vel aliquando ternatae in pedicellis brevissimis inaequalibus, $3.5-5 \mathrm{~mm}$ longae cuspides vel aristas excludentes, $1.75-2 \mathrm{~mm}$ latae turgidae late ellipticae acuminatae, in bases brevissimas stipitatas contrictae, cuspidatae vel breve aristatae vel sine aristis, virescentes vel purpurascentes, glumis et lemmate inferiore membranaceo-herbaceis. Gluma inferior longitudine $\frac{1}{2}-\frac{3}{5}$ lemmatis inferioris partes aequans, lata circa basem stipitatam spiculae constricta, basi late rotundata, sursum ad apicem acutum vel acuminatum vel subaristulatum abrupte angustata, 3-5-nervata, in dorso diffuse et tenuiter scabra, nervis longe scabris vel subspinulosis. Gluma superior spiculam subaequans, in dorso convexa, acuminata vel elongato-cuspidata vel breviter aristata, 5-nervata, in dorso praesertim sursum tenuiter scabra, in nervis tenuiter breviter tubercularospinulosa, spinulis $0.25-0.6 \mathrm{~mm}$ longis erecte angusteque divergentibus. Flosculus inferior neuter vel aliquando masculis: Lemma spiculam aequans, in dorso depressum marginibus late curvatis, 5-7-nervatum, alias glumam superiorem simulans, acuminatum vel cuspidatum vel aliquando arista usque ad $12(-25) \mathrm{mm}$ longa instructa; palea firme hyalina, ovato-oblonga, longitudine $\frac{3}{4}-\frac{7}{8}$ lemmatis 
partes aequans. Flosculus superior hermaphroditus, late ellipticus, planoconvexus, 3.5-3.75 mm longus, 1.5-1.8 $\mathrm{mm}$ latus, laevis: Lemma crustaceum, obscure 5-nervatum, obscure striolatum, in dorso convexissimum et nitens, ad apicem virescentem pubescentem aequaliter angustatum vel paullo constrictum; palea in dorso plana, quam lemma paullo brevior, textura simulans, marginibus convexis curvatis. Antherae 1-1.3 $\mathrm{mm}$ longae. Caryopsis ovato-ovalis, $1.8-2.2 \mathrm{~mm}$ longa, pallido-brunneola, embryone vix $\frac{3}{4}$ caryopsidis partes aequanti.

Holotype: New South Wales: Western Plains: Boorooma Creek, between Walgett and Brewarrina, $P$. Michael No. A 80, 27,ii.1968 (NSW 113971).

Tall, green to light green, glabrous annual, erect or somewhat geniculate at the lower nodes, up to $120 \mathrm{~cm}$ high. Culms up to $8 \mathrm{~mm}$ in diameter in the lower part, more slender upwards, smooth, very compressible, about 5-noded, terete to somewhat compressed, simple or sparingly branched. Nodes glabrous. Sheaths often as long as or longer than the internodes, the upper tight around the culm or somewhat inflated, the lower often becoming loose, at first firmly herbaceous, at length rather thin and papery, smooth, striate. Ligule glabrous, the collar rarely with a few sparse hairs on the sides. Blades linear, flat, narrowing upwards towards the acute or acuminate apex, gently rounded towards the base, up to $30 \mathrm{~cm}$ long and $12 \mathrm{~mm}$ wide, with a whitish midrib and 5-6 primary nerves on each side of it, the margins rather narrowly whitish-thickened and scabrous, otherwise smooth, occasionally with a few long tubercle-based hairs near the base. Panicle $7-20 \mathrm{~cm}$ long and scarcely $3-4 \mathrm{~cm}$ wide, slightly nodding, narrow, sublinear with erect or narrowly spreading, short racemes, the main axis slightly flexuose, scabrid, triquetrous, shortly scabrous on the angles, with rather few tubercle-based setae at the nodes and few or none between the nodes, bearing rather numerous distant racemes mostly as long as or exceeding the internodes between them, the racemes 1 -nate or sometimes 2 or 3 together and subverticillate, sparsely branching towards the base with short appressed branches, the lower racemes 2-6 $(-7) \mathrm{cm}$ long, the upper progressively shorter, secund, moderately densely to rather loosely furnished with spikelets, the rhachis triquetrous, scabrid and scabrous on the angles, without or with few branch setae, bearing alternately on each side of the mid-angle spikelets in pairs or more rarely in threes on very short unequal pedicels. Spikelets $3.5-5 \mathrm{~mm}$ long excluding the elongate cusps and awns when present, $1.75-2 \mathrm{~mm}$ broad, turgid, broadly elliptical, acuminate, constricted into a very short stipe-like base, cuspidate, unawned or rather shortly awned, at first green or purple-tinted or purple, the glumes and lower lemma membranous-herbaceous. Lower glume one-half to three-fifths as long as the lower lemma, broad and embracing the base of the spikelet and constricted around the stipe-like base with the margins slightly overlapping, when viewed from the back following the contour of the upper lemma rather evenly so that the spikelet is broadly rounded rather than truncate at the base, upwards narrowing somewhat abruptly into an acute, acuminate or subaristulate apex, 3- to 5-nerved, diffusely finely scabrous on the back, long-scabrous to subspinulose on the nerves. Upper glume almost as long as the spikelet, very convex on the back, acuminate to elongate-cuspidate or shortly awned, 5-nerved, finely scabrous on the back especially upwards, finely and shortly tuberculate-spinulose on the nerves with the evenly erectly or narrowly diverging spinules $0.25-0.6 \mathrm{~mm}$ long. Lower floret neuter, or sometimes staminate: Lemma as long as the spikelet, depressed on the back with broadly curving margins, 5- to 7-nerved, otherwise similar to the upper glume and similarly scabrous on the back and shortly tuberculate-spinulose on the nerves with spinules $0.25-0.6 \mathrm{~mm}$ long, acuminate or cuspidate or in some spikelets the awns of variable length up to $12(-25) \mathrm{mm}$; palea firmly hyaline, ovate-oblong, about three-quarters to seven-eighths as long as the lemma. Upper floret broadly elliptical, planoconvex, $3.5-3.75 \mathrm{~mm}$ long, $1.5-1.8 \mathrm{~mm}$ wide, smooth, shining, greenish or yellowish to at length yellowish-grey: Lemma 
crustaceous, obscurely 5-nerved, obscurely striolate, the shining yellowish back narrowing rather evenly into the greenish pubescent tip or slightly constricted just below the junction, very convex on the back; palea flat on the back, slightly shorter than the lemma and similar in texture and markings, with firm, smooth, convexly curving margins. Anthers $1-1.3 \mathrm{~mm}$ long, brownish or orange-yellow. Stigmas purple. Grain usually ovate-oval, 1.8-2.2 (usually 2) $\mathrm{mm}$ long, pale brownish, with the embryo scarcely three-quarters as long.

Distribution: In New South Wales in the Western Plains and Far Western Plains chieffy in the north, in or near water courses; also in Queensland in the Leichhardt, Burnett, Darling Downs and Warrego districts, and in South Australia along the Diamantina River channels.

\section{ACKNOWLEDGEMENTS}

The authors gratefully acknowledge the assistance of Dr L.A.S. Johnson and Dr M.D. Tindale in verifying the Latin descriptions provided above. 